\title{
Gender Participation in University Education in Nigeria: Closing the Gap
}

\author{
Akpoyovwaire Samuel Mukoro \\ Department of Educational Foundations and Administration, College of Education, \\ Warri, Delta State, Nigeria \\ Phone No.: 08038292196 \\ E-mail address: mukorosam@yahoo.com
}

\begin{abstract}
The National Policy on Education stipulated that there is need for equality of educational opportunities to all Nigerian children, irrespective of any real or imagined disabilities, each according to his or her ability. It further stressed that there will be the provision of equal access to educational opportunities for all citizens of the country at the primary, secondary and tertiary levels both inside and outside the formal school system. In spite of this policy commitment there still exists a wide gender disparity in university education in Nigeria. Therefore, this paper examines the concepts of gender and university education. Also, the paper highlights participation in university education by gender and locates the gender participation disparity barriers in university education in Nigeria. The paper concludes by identifying some intervention that can help close the existing gap between male and female in access to university education in Nigeria.
\end{abstract}

Keywords: University education; gender; participation; gap and parity

\section{INTRODUCTION}

The Nigerian government has enacted various policies geared towards attaining gender equality in access to every level of education (primary, secondary and tertiary). The National Policy on Education (FRN, 2004) emphasized the need for quality of educational opportunities to all Nigerian children, irrespective of any real or imagined disabilities, each according to his or her ability. It further stated that there will be the provision of equal access to educational opportunities for all citizens of the country at the primary, secondary and tertiary levels both inside and outside the formal school system. This provision on equality of opportunities was equally stressed in Section (18) of the 1999 National Constitution that government shall direct its policy towards ensuring that there are equal and adequate educational opportunities at all levels. The Dakar Conference also endorsed gender equity in participation in education.

The six Dakar goals that lay the foundations for global policy on quality education in the new millennium are the following:

- Expanding and improving comprehensive early childhood care and education, especially for the most vulnerable and disadvantaged children. 
- Ensuring that by 2015 all children, particularly girls, children in difficult circumstances and those belonging to ethnic minorities, have access to and complete, free and compulsory primary education of good quality.

- Ensuring that the learning needs of all young and adults are met through equitable access to appropriate learning and life-skills programmes.

- Achieving a 50 percent improvement in levels of adult literacy by 2015 , especially for women and equitable access to basic and continuing education for adults.

- Eliminating gender disparities in primary and secondary education by 2015, and achieving gender equality in education by 2015 , with a focus on ensuring girls' full and equal access to an achievement in basic education of good quality.

- Improving all aspects of the quality of education and ensuring excellence of all so that recognized and measurable learning outcomes are achieved by all, especially in literacy, numeric and essential life skills (UNESCO, 2002).

Also, one of the three action plans of 1998 World Conference on Higher Education was on the issue of "higher education and development" and representatives of the member states pledged to undertake action in fifteen (15) areas, three of which are to ensure that (1) higher education is equally accessible to all; (2) all persons seeking higher education have an optimal range of choices, and (3) the participation of women in higher education. These policies and action plans are consistent with Nigeria obligation in the constitution and National Policy on Education to ensure gender parity in higher (university) education.

Given the strong commitment within government to promote gender equality it is expected that Nigeria should have made impressive result in gender equitable access to university education.

However, outcome continue to fall short of the objectives which were targeted as girls still continue to trail behind boys in access to university education in Nigeria. As noted by Oyebade (2008) the challenge here is that nineteen years (1988) after the UNESCO's call, and eleven years (1996) after UNDP's call to address gender disparity, there still exists a wide gender disparity in university education/admission in Nigeria. In other words, he stressed, there is yet to be equality in access to university education between females and males.

An evidence of this could be found in Abubakar (2004) report that JAMB lamented the decline in the number of female candidates who sat for the examination from 438,703 in 2013 to 353,834 in 2014 .

In fact various social constructed barriers and entrenched social practices continue to result in disparity between male and female in access to university education. Therefore, identifying and remedying the source of continued disparity in male and female equitable access to university is mandatory in order to close the gap already existing in this sector.

The paper examines the concepts of gender; and university education, participation in university education by gender, locate barriers resulting in disparity in gender participation in university education and interventions to close the gap in gender disparities in university education in Nigeria. 


\section{UNDERSTANDING GENDER}

The term gender refers to social constriction of female and male identity. It can be defined as more than biological differences between men and women; it indicates the way in which those differences whether real or perceived have been valued, used and relied upon to clarify women and men to assign roles and responsibilities to them (Okunsebor, 2009). According to Jugale (2010) gender is used to denote the roles played by women and men and deals not only with differences (how a society constructs feminine and masculine people) but also with how the society connotes power on each of the sexes. As such gender determines what is expected, allowed and valued in a woman or man in a given context.

In most societies, there are differences and inequalities between men and women, in most society's men are assigned special responsibilities, they are made to undertake special activities, they are made to have access to and control over resources, as well as decision making opportunities (Patrick, 2010). According to Egunyomi, Fadeyi, Folaranmi \& Adelore (2001) gender connotes feminity and masculinity. They emphasized that masculinity characteristics in Africa for example include bread winner and head of family, strong vigilant and adventurous, never cries or display emotions and engages in male's games such as wrestling. Feminine characteristics on the other hand include taking care of domestic chores, very emotional, engages in female games such as dancing. In effect gender is the identification of the sexes influenced by cultural factors such as socio-cultural, religion, economic among others.

\section{UNIVERSITY EDUCATION IN NIGERIA}

Universities are citadel of learning for the development of expertise and high level manpower necessary for technological and sustainable development. Igwe \& Ilechukwu (2013) presented a university as a social institution whose basic missions are to preserve the cultural heritage of society, generate new knowledge and transmit it. A university is an agent for shaping not only the destiny of the individual, but also of the nation. In Nigeria, the existence of university started in 1948 with the establishment of the University College, Ibadan, followed by the first indigenous university, University of Nigeria, Nsukka in 1960. Others include Ahmadu Bello University, Zaria in 1961, University of Ife (later changed to Obafemi Awolowo University (OAU)), Ile-Ife in 1962, University of Lagos, Lagos in 1962. Table 1 below shows the first five Nigerian universities and their enrolment figure for the $1962-63$ academic year. 
Table 1. First Five Nigerian Universities and the Enrolment Figures, 1962 - 63 Academic Year.

\begin{tabular}{|c|c|c|c|c|c|c|c|c|c|c|c|c|}
\hline$z_{\infty}$ & 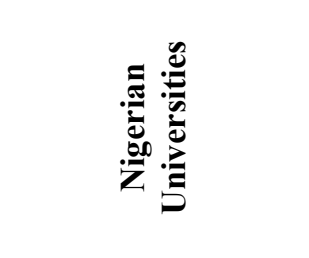 & 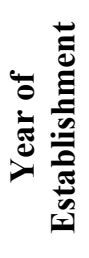 & $\bar{Z}$ & 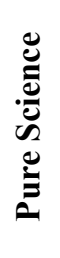 & 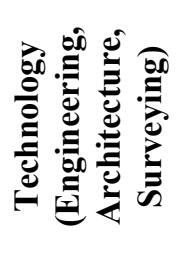 & 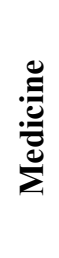 & 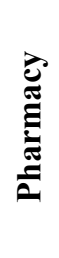 & 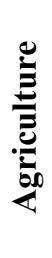 & 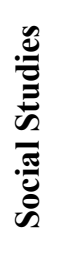 & 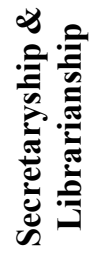 & 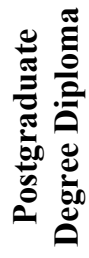 & हैं \\
\hline 1. & University of Ibadan & $\stackrel{\infty}{\stackrel{+}{\sigma}}$ & in & $\hat{\text { mे }}$ & ' & సે & ' & $\stackrel{0}{=}$ & $\stackrel{N}{I}$ & $=$ & $\stackrel{\infty}{n}$ & $\stackrel{2}{?}$ \\
\hline 2. & $\begin{array}{c}\text { University of } \\
\text { Nigeria, Nsukka }\end{array}$ & $\stackrel{8}{2}$ & $\underset{ల}{\stackrel{D}{~}}$ & $\stackrel{\mathscr{Z}}{\sim}$ & 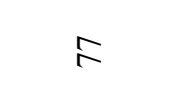 & ' & ' & ๙ & $\vec{\infty}$ & gे & & $\underset{\sim}{\stackrel{J}{Z}}$ \\
\hline 3. & $\begin{array}{l}\text { Ahmadu Bello } \\
\text { University }\end{array}$ & ఫे & $\stackrel{\infty}{\infty}$ & $\simeq$ & $\vec{\overbrace{}}$ & 1 & ' & $\infty$ & $\stackrel{\infty}{\infty}$ & ' & ' & $\hat{\sigma}$ \\
\hline 4. & $\begin{array}{l}\text { University of Ife } \\
\text { (now OAU) }\end{array}$ & స్ర & in & $\hat{\gamma}$ & ' & ' & 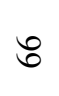 & $\mathscr{2}$ & $\hat{n}$ & $\because$ & ' & $\underset{\sim}{\mathbb{Z}}$ \\
\hline 5. & University of Lagos & ర్ర & ' & , & ' & $\stackrel{\infty}{\sim}$ & ' & ' & $\cong$ & 1 & , & 으 \\
\hline & Total & & $\bar{a}$ & gे & $\stackrel{\infty}{\triangleq}$ & సి & 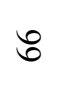 & $\widehat{\sim}$ & J゙ & $\stackrel{n}{n}$ & $\stackrel{\infty}{n}$ & $\frac{\vec{b}}{m}$ \\
\hline
\end{tabular}

Source: Report of the National Universities Commission (1963) in Fafunwa (1980) New Perspectives in African Education.

Thereafter Nigeria established more universities (both federal and state) probably to cater for the constantly high rate of unsatisfied demand for university education. Some of such federal universities include Bayero University, Kano (1976), Usman Dan Fidio University, Sokoto (1976), University of Port-Harcourt (1976), University of Ilorin (1976) and University of Calabar (1976). Also, in modern times the private sector and religious bodies have equally established private universities. Available statistics show that Nigeria has about one hundred and twenty-nine (129) universities (federal, state and private).

The goals of university education as contained in the Federal Republic of Nigeria National Policy on Education (FRN, 2004) include the followings:

a. contribute to national development through high level relevant manpower training;

b. develop and inculcate proper values for the survival of the individual and society;

c. develop the intellectual capacity of individuals to understand and appreciate their local and external environments;

d. acquire both physical and intellectual skills which will enable individuals to be selfreliant and useful members of the society;

e. promote and encourage scholarship and community services; 
f. forge and cement national unity; and

g. promote national and international understanding and interaction.

In essence university being the highest institution of learning should educate tomorrows' citizens, professionals, captains of industries, leaders and foster the discovery of new knowledge that may either strengthen or challenge established ideas and norms all with the aim of deepening human understanding and bettering the human condition (Igwe \& Ilechukwu, 2013). This means that there should be need to achieve equitable participation of both male and female in university education in Nigeria. Although Nigeria has the largest university system in Sub-Sahara Africa, unfortunately, Nigeria's university density remains one of the lowest in the world (Okunade, 2011).

\section{PARTICIPATION IN UNIVERSITY EDUCATION BY GENDER}

There are consistent evidence on statistical difference between male and female enrolment in university education in Nigeria. Giving credence to this, Omoike (2010) remarked that there seems not to be comparative increase in enrolment rate of females as for the males over the years. Table 2 below shows university male and female admission rates in South-South geo-political zone 2000 to 2004.

Table 2. University Male and Female Admission Rates in South-South Geo-Political Zone $2000-2004$.

\begin{tabular}{|c|c|c|c|c|c|c|c|c|c|c|c|c|c|c|c|c|}
\hline State & & $\mathbf{M}$ & $\mathbf{F}$ & $\mathbf{T}$ & $\mathbf{M}$ & $\mathbf{F}$ & $\mathbf{T}$ & $\mathbf{M}$ & $\mathbf{F}$ & $\mathbf{T}$ & $\mathbf{M}$ & $\mathbf{F}$ & $\mathbf{T}$ & $\mathbf{M}$ & $\mathbf{F}$ & $\mathbf{T}$ \\
\hline Bayelsa & $\begin{array}{l}\mathrm{N} \\
\%\end{array}$ & $\begin{array}{l}418 \\
62.3\end{array}$ & $\begin{array}{l}253 \\
37.7\end{array}$ & 671 & $\begin{array}{r}1587 \\
64.7\end{array}$ & $\begin{array}{l}862 \\
35.3\end{array}$ & 2445 & $\begin{array}{r}667 \\
67.8\end{array}$ & $\begin{array}{r}347 \\
34.2\end{array}$ & 1014 & $\begin{array}{l}2491 \\
62.7\end{array}$ & $\begin{array}{l}1481 \\
37.2\end{array}$ & 3972 & $\begin{array}{r}2560 \\
61.1\end{array}$ & $\begin{array}{r}1631 \\
38.9\end{array}$ & 4191 \\
\hline Delta & $\begin{array}{l}\mathrm{N} \\
\%\end{array}$ & $\begin{array}{l}2494 \\
58.2\end{array}$ & $\begin{array}{l}1763 \\
41.8\end{array}$ & 4217 & $\begin{array}{r}3859 \\
58.5\end{array}$ & $\begin{array}{l}2742 \\
41.5\end{array}$ & 6601 & $\begin{array}{r}2289 \\
58.9\end{array}$ & $\begin{array}{r}1598 \\
41.1\end{array}$ & 3887 & $\begin{array}{r}3930 \\
58.5\end{array}$ & $\begin{array}{l}2787 \\
41.5\end{array}$ & 6717 & $\begin{array}{l}5214 \\
54.8\end{array}$ & $\begin{array}{l}4300 \\
45.2\end{array}$ & 9514 \\
\hline Edo & $\begin{array}{l}\mathrm{N} \\
\%\end{array}$ & $\begin{array}{c}2118 \\
60.3\end{array}$ & $\begin{array}{l}1397 \\
39.7\end{array}$ & 3515 & $\begin{array}{l}2149 \\
61.5\end{array}$ & $\begin{array}{l}1344 \\
38.5\end{array}$ & 3493 & $\begin{array}{r}1861 \\
62.1\end{array}$ & $\begin{array}{r}1135 \\
37.9\end{array}$ & 2996 & $\begin{array}{r}3941 \\
59.1\end{array}$ & $\begin{array}{c}2724 \\
40.9\end{array}$ & 6665 & $\begin{array}{l}3824 \\
57.7\end{array}$ & $\begin{array}{r}2806 \\
42.3\end{array}$ & 6630 \\
\hline Total & $\begin{array}{l}\mathrm{N} \\
\%\end{array}$ & $\begin{array}{r}7846 \\
58.7\end{array}$ & $\begin{array}{r}5089 \\
41.3\end{array}$ & $\begin{array}{c}12335 \\
100\end{array}$ & $\begin{array}{c}13364 \\
61.5\end{array}$ & $\begin{array}{l}8938 \\
38.5\end{array}$ & $\begin{array}{c}22302 \\
100\end{array}$ & $\begin{array}{r}8673 \\
57.5\end{array}$ & $\begin{array}{r}6413 \\
42.5\end{array}$ & $\begin{array}{c}15086 \\
100\end{array}$ & $\begin{array}{c}17583 \\
57.7\end{array}$ & $\begin{array}{c}12883 \\
42.3\end{array}$ & $\begin{array}{c}30466 \\
100\end{array}$ & $\begin{array}{r}18782 \\
54.4\end{array}$ & $\begin{array}{r}15736 \\
45.6\end{array}$ & $\begin{array}{c}34518 \\
100\end{array}$ \\
\hline
\end{tabular}

Key: $\mathrm{N}=$ Number of admission; $\%=$ Percentage, $\mathrm{M}=$ Male; $\mathrm{F}=$ Female and $\mathrm{T}=$ Total

Source: Omoike, D. (2010). Sensitizing the Female in University Admission in South-South Geopolitical Zone for Assurance of Sustainable Development in Nigeria

Table I above indicated that, there has been a steady increase in admission into universities from the South-South geopolitical zone of Nigeria between 2000 and 2004. From 
12,335 in 2000 , it rose to 34,518 in 2004 . A variation in the trend was noticed in 2001 when 22,302 candidates were admitted. The males continued to dominate in admission from 2001 to 2004. The dominance was prominent in all the six states with the only exception in the 2002 admission for Akwa-Ibom with $50.2 \%$ for females as against $49.8 \%$ for males. Of all the states in the zone, only Delta and Rivers consistently had female enrolment rate of slightly above $40 \%$ for the five year period under study (2000 to 2004). The pattern of gender enrolment had consistently differ significantly across zones. For instance, Adeyemi \& Akpotu (2004) reported that the Middle Belt and the core North had the lowest female and even the male enrolment. According to them, the total percentage female enrolment of the core North in all Nigerian universities ranged between 3.87 (of total female enrollees) in $1995 / 96$ academic session to $10.40 \%$ in 1990/91 session. The Middle Belt percentage female enrolment, they reported, ranged between $6.56 \%$ in 1998/99 session and $11.32 \%$ in 1996/97 session. Okolo (2001) reported that the trend in male enrolment into different universities (states and federal) has continued to be higher than their female counterparts. Making reference to National University Commission (NUC) records, she reported that during the 1991/92 academic session the trend of male and female students enrolment to university education in Anambra State was 9,462 for males and only 7,264 for females. While Sokoto during 1991/92 academic session male enrolment into higher education was 854 while female enrolment was 134.

Furthermore, looking at gender participation in university education in Nigeria base on faculty enrolment, Adeyemi \& Akpotu (2004) found the highest proportion of female enrolment $(42.13 \%)$ to come from the faculty of education followed by the faculty of arts $(36.2 \%)$ while the lowest percentages were obtained in the faculties of engineering, technology and environmental design in universities in Nigeria. Although in recent times there seems to be a sharp increase in female enrolment into universities but there still exist a clear disparity between male and female enrolment in Nigeria. Table 3 below indicated the trends in male and female enrolment in university education in Nigeria for the period 2003 and 2008 .

Table 3. Total Number of Universities enrolment between 2003 and 2008.

\begin{tabular}{|c|c|c|c|c|c|c|c|c|c|}
\hline \multicolumn{2}{|c|}{$2003 / 2004$} & \multicolumn{2}{|c|}{$2004 / 2005$} & \multicolumn{2}{c|}{$\mathbf{2 0 0 5 / 2 0 0 6}$} & \multicolumn{2}{c|}{ 2006/2007 } & \multicolumn{2}{c|}{ 2007/2008 } \\
\hline Male & Female & Male & Female & Male & Female & Male & Female & Male & Female \\
\hline 603,176 & 443,764 & 484,217 & 353,834 & 527,180 & 390,780 & 521,170 & 391,180 & 578,715 & 455,368 \\
\hline
\end{tabular}

Source: Joint Admission and Matriculation Board, 2009.

The table above shows very little progress in closing gender gap in university enrolment over the period of 2003 and 2008.

\section{LOCATING THE GENDER PARTICIPATION DISPARITY BARRIERS IN UNIVERSITY}

The gender participation disparity in university education is a function of several interacting factors. For instance, the constraints arising from the socio-cultural norms such as forced marriages, early child bearing and rearing, gender biased teaching and educational 
materials, and girls responsibility for heavy domestic work at early stage continue to curtail girls access to education, thus making it difficult for them to acquire higher (university) education (African Development Bank, 2002). Other barriers include religion, parental influence, the matrilineal social system, conservation in tradition and culture, early marriage and the purdah system, examination performance, low literacy level of parents, poverty and lack of government policy on women education, inadequate provision of secondary schools for girls and sexual harassment in educational institutions leading to unwanted pregnancies and early withdrawals by girls. In brief, Singh (2002) identified the common set of barriers to be tackled. The major ones among them are:

- Endemic poverty;

- Schooling costs;

- The burden of household labour;

- $\quad$ Shortage of school facilities, especially in rural areas;

- Negative and even dangerous school environments;

- Cultural and social practices that discriminate against girls, including early marriage and restriction on female mobility and

- Limited employment opportunities for women.

\section{INTERVENTION TO CLOSE GENDER GAP IN UNIVERSITY IN NIGERIA}

\section{- Policy Measures}

Policies designed by the Nigeria Government that hold the potential to remedy the existing disparity in male and female enrolment in university education should be honestly focus on and prioritized to make sure that they meet the strategic target. In particular, there is a need to build proactive policy interventions to manage the various sources of direct and indirect bias working against the girls education in Nigeria.

- Affirmative Action (AA)

Affirmative Action (AA) take place when government go out of its usual way (take positive action) to increase the likelihood of true equality for both male and female students of different background in access to education. This according to Bunyi (2004) should have various components geared towards ensuring gender parity in university education. The components should include:

1. Lowering cut-off university admission point for female candidates by one point.

2. Remedial courses targeted to increase female enrolment in highly competitive Science, Mathematical and Technology (SMT) related programmes and

3. Outreach programmes.

In fact, consistent with the provision in the National Policy on Education and the constitution, the Nigeria government should faithfully implement affirmative action measures to ensure equal participation and enrolment of both male and female in university education.

\section{- Gender-Disaggregated Data Collection}

Since the responsibility to ensure gender policies implementation rest on government particularly and the education sector in general, there is need for government to ensure 
gender-disaggregated data collection at all levels of education continues monitoring and evaluation of progress toward gender parity.

- Expansion of University Education

The expansion of universities in Nigeria to accommodate the high demand for university education at both undergraduate and graduate levels can be achieved through various strategies viz:

1. by increased state investment;

2. by increased private sector participation;

3. by the rise of offshore and satellite expansion;

4. by distance education mode which has properly addressed the problems of equity, quality and cost, apart from access (Oyebade, 2008).

- Education Budgetary Commitments

The government should show commitment to adequate funding of education by striving to meet the UNESCO recommended 26 percent of annual budget to education. The government must equally ensure that budget meant for education be adhered to and prioritized to expand and improve physical facilities and equipment in universities as this will go a long way to enhance carrying capacity to admit more applicants. Also with committed funding, government can give tuition waiver of 20 percent and incentives such as scholarship to female students to enhance their participation and enrolment in university education. To achieve this, government should establish Human Capital Development Trust Fund to be located in the universities in Nigeria.

Also, Adeyemi \& Akpotu (2004:374 - 376) suggested that there should be:

1. Determined effort at increasing female enrolment at all levels of education, especially through extensive public enlightenment programmes, especially through the mass media, community and religious leaders. The positive values of women education to the individual and nation should be disseminated.

2. Persuasion of parents to see reasons for the girl-child education should be adopted. Parents should be persuaded through sustained enlightenment, adult education and non-formal education programmes to identify evil effects of illiteracy and early marriage, especially in the northern part of the country, where this practice is prevalent.

In effect, all these interventions will enhance parity in male and female participation in university education in Nigeria.

\section{CONCLUSION}

The paper examined the concepts of gender and university education. It also discussed the level of participation in university education by gender and located some of the gender participation disparity barriers in university education in Nigeria. Some of such barriers are endemic poverty, schooling cost, the burden of household labour, shortage of school facilities, negative and even dangerous school environment, cultural and social practices that discriminate against girls including early marriage and restriction on female mobility and 
limited employment opportunities for women. Finally, some interventions to ensure gender parity of male and female in university education were identified with the hope of closing the existing gender gap in the sector.

\section{References}

[1] Adeyemi, K. \& Akpotu, N. (2004). Gender Analysis of Student Enrolment in Nigerian Universities. Higher Education, 48; 361-378.

[2] African Development Bank (ADB) (2002). Gender, Poverty and Environmental Indicators on African Countries. Abidjan: ADB.

[3] Bunyi, G.W. (2004). Gender Disparities in Higher Education in Kenya: Nature, Extent and the Way Forward. The African Symposium, 4(1).

[4] Egunyomi, D., Fadeyi, T., Folaranmi, F. \& Adelore, F. (2001). Women Education and Development. In J.T. Okedara, C.N. Ayawu \& M.A. Omole (eds) Rethinking Adult and Non-Formal Education. Ibadan: Stirling-Hoden Publishers.

[5] Fafunwa, A.B. (1980). New Perspectives in African Education. London: Macmillan Education Limited.

[6] Federal Republic of Nigeria (1999). 1999 Constitution of the Federal Republic of Nigeria. Lagos: Government Printer.

[7] Federal Republic of Nigeria (2004). National Policy on Education. Lagos: NERDC

[8] Igwe, L.E.B. \& Ilechukwu, P.E. (2013). Effect of Selection of Vice-Chancellors on Effective Administration of Universities. African Journal of Higher Education Studies and Development, 1(1); 91-118.

[9] Joint Admission and Matriculation Board (2009) Statistical Analysis

[10] Jugale, V.B. (2006). Poverty, Globalization and Human Development. New Delhi: Serials Publication.

[11] Okolo, A.N. (2001). Gender Inequality in Nigeria: A Challenge for Educational Advancement in Developing Countries. In A.U. Akubue \& D. Enyi (eds) Crises and Challenges in Higher Education in Developing Countries: A Book of Readings. Ibadan: Wisdom Publishers Ltd.

[12] Okunade, B. (2011). Open Distance Learning: A Viable Option to Varsity Education. Ibadan: University of Ibadan Distance Learning Centre.

[13] Okunsebor, M.I.U. (2009). Women Empowerment and Development: Panacea for Gender Equality and Sustainable Development. Benin Journal of Educational Studies, $19(1 \& 2) ; 276-284$.

[14] Omoike, D. (2010). Sensitizing the Female in University Admission in South-South Geopolitical Zone for Assurance of Sustainable Development in Nigeria. International Journal of Educational Administration and Policy Studies, 2(8); 113117.

[15] Oyebade, S.A. (2008). Gender Participation in University Education in Nigeria and Some Commonwealth Countries. Retrieved on February $10^{\text {th }}, 2013$ from http://nigeriaworld.com/articles/html 
[16] Patrick, O. (2010). Gender and Teacher Education in Nigeria. Journal of Research in Education and Society, 1(1); 166-177.

[17] Singh, J.K.S. (2002). Women and Management in Higher Education: A Good Practice Book. Paris Association for Commonwealth Universities: UNESCO.

[18] Mohsen Mehrara, Hamid Abrishami, Mostafa Boroujli, Mahan Amin, International Letters of Social and Humanistic Sciences 11 (2013) 76-83.

[19] Andrzej Borowski, International Letters of Social and Humanistic Sciences 11 (2013) 100-105.

[20] Sele Sylvester Ebisin, International Letters of Social and Humanistic Sciences 2 (2014) 1-9.

[21] Pawa Tersoo, International Letters of Social and Humanistic Sciences 3 (2014) 26-36.

[22] Adoga James Ada, International Letters of Social and Humanistic Sciences 3 (2014) 45-52.

[23] Bahram Meihami, Hussein Meihami, International Letters of Social and Humanistic Sciences 3 (2014) 80-91.

[24] Onyike Maggaret Odu, International Letters of Social and Humanistic Sciences 4 (2014) 31-39.

[25] Uloma Charity Oguzor, International Letters of Social and Humanistic Sciences 4 (2014) 97-104.

[26] Okezie A. Ihugba, Alex Odii, A. C. Njoku, International Letters of Social and Humanistic Sciences 5 (2014) 21-34.

[27] Okezie A. Ihugba, Bankoli Bankong, N. C. Ebomuche, International Letters of Social and Humanistic Sciences 5 (2014) 92-113.

[28] Donovan A. McFarlane, International Letters of Social and Humanistic 4 (2013) 35-44.

[29] Paul Bukuluki, International Letters of Social and Humanistic 5 (2013) 27-44.

[30] Uloma Charity Oguzor, International Letters of Social and Humanistic 4 (2014) 97-104.

[31] Okezie A. Ihugba, Alex Odii, A. C. Njoku, International Letters of Social and Humanistic 5 (2014) 21-34.

[32] Okezie A. Ihugba, Bankoli Bankong, N. C. Ebomuche, International Letters of Social and Humanistic 5 (2014) 92-113. 